\title{
PENGARUH KITOSAN TERHADAP KRISTALINITAS DAN MORFOLOGI PARTIKEL LITHIUM TITANAT
}

\section{THE EFFECT OF CHITOSAN ON CRYSTALLINITY AND MORFOLOGY OF LITHIUM TITANATE PARTICLE}

\author{
Bharata Dewanto ${ }^{1}$, Bambang Sunendar Purwasasmita ${ }^{1}$, Ahmad Nuruddin ${ }^{1}$, Abdul Halim \\ Daulay $^{2,4}$, Susanto Sigit Rahardi ${ }^{3}$ \\ ${ }^{1}$ Program Studi Teknik Fisika, Fakultas Teknologi Industri, Institut Teknologi Bandung, \\ Jl. Ganesha No. 10 Bandung \\ ${ }^{2}$ Pogram Studi Ilmu dan Teknik Metal, Institut Teknologi Bandung, Jl. Ganesha No. 10 Bandung \\ ${ }^{3}$ Balai Besar Bahan dan Barang Teknik (B4T), Jl. Sangkuriang No. 14 Bandung \\ ${ }^{4}$ Institut Agama Islam Negeri Sumatera Utara, Jl. Williem Iskandar Pasar V, Medan Estate, Medan
}

Diterima: 28 Oktober 2014

Direvisi: 19 November 2014

Disetujui: 16 Desember 2014

\begin{abstract}
ABSTRAK
Baterai terdiri dari katoda, anoda, dan elektrolit. Lithium titanat spinel atau $\mathrm{Li}_{4} \mathrm{Ti}_{5} \mathrm{O}_{12}$ spinel adalah metal anoda alternatif untuk menggantikan karbon karena memiliki kemampuan untuk memberikan arus besar yang dapat diaplikasikan sebagai baterai pada mobil listrik. Metode yang saat ini sering digunakan untuk pembuatan baterai adalah High Energy Ball Milling, namun energi yang dibutuhkan sangat besar dan waktu pengerjaan dengan metode ini pun cukup lama. Dalam penelitian ini dilakukan sintesis serbuk $\mathrm{Li}_{4} \mathrm{Ti}_{5} \mathrm{O}_{12}$ sebagai anoda baterai lithium ion dengan metode sol-gel dengan variabel kitosan sebagai dispersing agent. Gel yang terbentuk dikalsinasi pada variasi suhu $750^{\circ} \mathrm{C}$. Serbuk hasil sintesis dikarakterisasi menggunakan metode XRD (X-ray Diffractometry) dan SEM (Scanning Electron Microscopy). Pada penelitian ini telah berhasil disintesis $\mathrm{Li}_{4} \mathrm{Ti}_{5} \mathrm{O}_{12}$ dengan metode sol-gel dengan kitosan sebagai dispersing agent. Pada suhu kalsinasi $750^{\circ} \mathrm{C}$ terbentuk $95-97 \%$ fasa $\mathrm{Li}_{4} \mathrm{Ti}_{5} \mathrm{O}_{12}$ yang diketahui dari berdasarkan hasil karakterisasi XRD, kitosan berperan baik sebagai dispersing agent karena dapat meningkatkan kristalinitas, memperkecil ukuran partikel dari serbuk $\mathrm{Li}_{4} \mathrm{Ti}_{5} \mathrm{O}_{12}$, dan mengurangi aglomerasi partikel. Hasil pengamatan dengan SEM menunjukkan bahwa ukuran dari partikel tergolong pada ukuran submikron yaitu berkisar 75-300 nm yang berpotensi sebagai metal anoda baterai lithium yang mendekati kapasitas secara teori.
\end{abstract}

Kata kunci: baterai lithium ion, anoda, $\mathrm{Li}_{4} \mathrm{Ti}_{5} \mathrm{O}_{12}$, sol-gel, kitosan

\begin{abstract}
Battery consists of cathode, anode, and electrolyte. Spinel Lithium Titanate, known as $\mathrm{Li}_{4} \mathrm{Ti}_{5} \mathrm{O}_{12}$ spinel is an alternative metal for anode substituting carbon due to its ability to generate large current for high-discharged battery. It can be applied for the electric car battery. A commonly used battery synthesis method is High Energy Ball Milling. However, that method is time consuming and require massive amount of energy. In this research, $\mathrm{Li}_{4} \mathrm{Ti}_{5} \mathrm{O}_{12}$ Synthesized as an anode for lithium ion battery through sol-gel method with chitosan variable as the dispersing agent. Formed gel then calcinated with temperature of $750^{\circ} \mathrm{C}$. Synthesized powder was characterized using XRD (X-ray Diffractometry) and SEM (Scanning Electron Microscopy) methods. $\mathrm{Li}_{4} \mathrm{Ti}_{5} \mathrm{O}_{12}$ was successfully synthesized with sol-gel method and chitosan as the dispersing agent. Based on the XRD characterization result, at the $750^{\circ} \mathrm{C}$ calcination temperature, $95-97 \%$. $\mathrm{Li}_{4} \mathrm{Ti}_{5} \mathrm{O}_{12}$ phase was formed. Chitosan played a good role of being the dispersing agent because it was able to increase crystallinity, reduce the size of $\mathrm{Li}_{4} \mathrm{Ti}_{5} \mathrm{O}_{12}$ powder particle, and reduce the particle agglomeration. Observation with SEM shows that the particle size is categorized as submicron, which size is ranged in 75-300 nm. It is potential to be used as the metal for lithium battery anode that come near to theoretical capacity.
\end{abstract}

Keywords: lithium ion battery, anode, $\mathrm{Li}_{4} \mathrm{Ti}_{5} \mathrm{O}_{12}$, sol-gel, chitosan 


\section{PENDAHULUAN}

Mobil listrik adalah salah satu kendaraan yang menggunakan energi listrik untuk menggerakkan motornya. Penggunaan listrik merupakan salah satu alternatif untuk mengurangi pemakaian bahan bakar fosil pada sektor transportasi. Penelitian mobil listrik di Indonesia terus berkembang dan keberadaan mobil listrik tidak dapat dipisahkan dengan kebutuhan media penyimpan energi yang ringan namun dapat memberikan arus besar [1].

Baterai adalah salah satu media penyimpan energi. Baterai bekerja dengan menggunakan prinsip sel volta yang mampu mengubah potensi elektrokimia menjadi energi listik. Baterai terdiri dari tiga bagian yaitu katoda, anoda, dan elektrolit. Katoda berfungsi sebagai kutub positif, anoda berfungsi sebagai kutub negatif dan elektrolit berfungsi sebagai jembatan untuk transport ion antara katoda dan anoda. Penelitian tentang baterai sudah sejak lama dikembangkan. Beberapa jenis baterai yang telah dikembangkan adalah Ni-MH, Ni-Cd, Lead acid, dan yang saat ini sedang dikembangkan secara intensif adalah baterai berbasis lithium [2].

Prinsip kerja baterai lithium tidak jauh berbeda dengan baterai lain, namun densitas energi dan kapasitas energi baterai lithium lebih baik dibandingkan baterai lain. Baterai lithium dibedakan jenisnya berdasarkan metal penyusun elektroda dan elektrolitnya karena kapasitas dan densitas baterai lithium dipengaruhi oleh metal penyusun katoda, anoda, dan elektrolitnya. Metal penyusun anoda atau kutub negatif baterai yang saat ini banyak digunakan adalah karbon karena memiliki potensi elektrokimia yang rendah sehingga tegangan yang didapat cukup tinggi. Namun untuk aplikasi mobil listrik yang membutuhkan arus besar, anoda berbasis karbon kurang stabil dan tidak dapat menghasilkan arus yang besar. $\mathrm{Li}_{4} \mathrm{Ti}_{5} \mathrm{O}_{12}$ yang memiliki struktur spinel adalah salah satu anoda alternatif pengganti karbon. $\mathrm{Li}_{4} \mathrm{Ti}_{5} \mathrm{O}_{12}$ memiliki kestabilan yang tinggi karena struktur kristalnya yang cenderung tidak berubah saat mengalami interkalasi dan deinterkalasi [3], selain itu arus yang dapat dihasilkan dengan anoda berbahan $\mathrm{Li}_{4} \mathrm{Ti}_{5} \mathrm{O}_{12}$ lebih besar dibandingkan karbon. Walaupun demikian, ada masalah-masalah lain seperti potensi elektrokimia $\mathrm{Li}_{4} \mathrm{Ti}_{5} \mathrm{O}_{12}$ lebih tinggi dan juga kapasitasnya yang lebih rendah dibandingkan anoda berbasis karbon [4]. Oleh karena itu, diperlukan penelitian lebih lanjut untuk memodifikasi $\mathrm{Li}_{4} \mathrm{Ti}_{5} \mathrm{O}_{12}$ sehingga memiliki densitas energi lebih tinggi dari sebelumnya.

Metode Ball Milling adalah metode sintesis $\mathrm{Li}_{4} \mathrm{Ti}_{5} \mathrm{O}_{12}$ yang sering digunakan namun metode tersebut membutuhkan energi yang besar dan juga waktu yang cukup lama. Metode sol-gel adalah metode terbaru yang sederhana, hemat energi dan juga tidak memakan waktu lama dapat menjadi alternatif dalam sintesis metal $\mathrm{Li}_{4} \mathrm{Ti}_{5} \mathrm{O}_{12}$. Pertumbuhan partikel pada metode sol-gel dapat dikendalikan dengan menggunakan dispersing agent. Kitosan merupakan biopolimer yang jumlahnya sangat banyak di Indonesia dan dapat berperan sebagai dispersing agent dalam metode sol-gel. Hasil yang diharapkan dari sintesis ini adalah kitosan dapat berperan baik dalam mengendalikan pertumbuhan partikel $\mathrm{Li}_{4} \mathrm{Ti}_{5} \mathrm{O}_{12}$ sehingga didapatkan partikel $\mathrm{Li}_{4} \mathrm{Ti}_{5} \mathrm{O}_{12}$ berukuran nanometer. Tujuan dari penelitian ini adalah untuk mengetahui pengaruh penambahan kitosan terhadap morfologi dan kristalinitas Lithium Titanat.

\section{BAHAN DAN METODE}

\section{Bahan}

Bahan yang dipakai dalam penelitian ini adalah $\mathrm{LiNO}_{3}, \mathrm{TiCl}_{4}$ dan kitosan. Adapun proses pembuatan Lithium Titatnat adalah sebagai berikut:

1. Membuat larutan kitosan $2 \%$ massa/volume.

2. Melarutkan $\mathrm{LiNO}_{3}$ hingga diperoleh larutan LiOH berwarna bening.

3. Melarutkan $\mathrm{TiCl}_{4}$ hingga diperoleh larutan $\mathrm{Ti}(\mathrm{OH})_{4}$.

4. Mencampurkan larutan $\mathrm{LiOH}$ dan larutan $\mathrm{Ti}(\mathrm{OH})_{4}$ tersebut secara perlahan-lahan sambil diaduk.

5. Larutan kitosan 2\% ditambahkan kedalam larutan setetes demi setetes sambil diaduk. Banyaknya larutan kitosan yang ditambahkan adalah sebesar $0,10,30$, dan $60 \%$ dari volume larutan.

6. Evaporasi pelarut secara termal pada suhu 90$100^{\circ} \mathrm{C}$.

7. Gel yang terbentuk digerus agar menjadi serbuk yang halus.

8. Kalsinasi serbuk pada suhu $750^{\circ} \mathrm{C}$.

9. Serbuk $\mathrm{Li}_{4} \mathrm{Ti}_{5} \mathrm{O}_{12}$ yang terbentuk dikarakterisasi dengan alat XRD dan SEM. 


\section{HASIL DAN PEMBAHASAN}

\section{Pengaruh Persentase Kitosan}

Pada suhu kalsinasi $750^{\circ} \mathrm{C}$ terlihat perbedaan yang signifikan pada contoh yang disintesis tanpa kitosan dengan yang disintesis menggunakan kitosan sebagai dispersing agent seperti yang terlihat pada Gambar 1. Hasil XRD pada Gambar 2 dan Tabel 1 juga memperlihatkan peningkatan fasa $\mathrm{Li}_{4} \mathrm{Ti}_{5} \mathrm{O}_{12}$ yang terbentuk. Pada contoh dengan $30 \%$ kitosan, partikel terdispersi merata dan berukuran antara 75-300 nm dan pada contoh dengan $60 \%$ kitosan partikel relatif lebih kecil dibandingkan contoh dengan 30\% kitosan namun tidak terdispersi merata. Hal ini disebabkan karena penggunaan kitosan atau dispersing agent yang terlalu banyak menyebabkan performa dispersing agent tersebut menurun.

Tabel 1.Komposisi Serbuk berdasarkan jumlah Kitosan dengan Suhu Kalsinasi $750^{\circ} \mathrm{C}$

\begin{tabular}{ccccc}
\hline Contoh & $\begin{array}{c}\text { Jumlah } \\
\text { Kitosan }\end{array}$ & $\begin{array}{c}\text { Suhu } \\
\text { Kalsinasi }\end{array}$ & $\begin{array}{c}\mathrm{Li}_{4} \mathrm{Ti}_{5} \mathrm{O}_{12} \\
\text { (\% berat) }\end{array}$ & $\begin{array}{c}\mathrm{TiO}_{2} \\
\text { (\% berat) }\end{array}$ \\
\hline $\mathrm{a}$ & $0 \%$ & $750^{\circ} \mathrm{C}$ & $94,8 \%$ & $5,2 \%$ \\
\hline $\mathrm{b}$ & $10 \%$ & $750^{\circ} \mathrm{C}$ & $95 \%$ & $5 \%$ \\
\hline $\mathrm{c}$ & $30 \%$ & $750^{\circ} \mathrm{C}$ & $97,5 \%$ & $2,5 \%$ \\
\hline $\mathrm{d}$ & $60 \%$ & $750^{\circ} \mathrm{C}$ & $97,4 \%$ & $2,6 \%$ \\
\hline
\end{tabular}

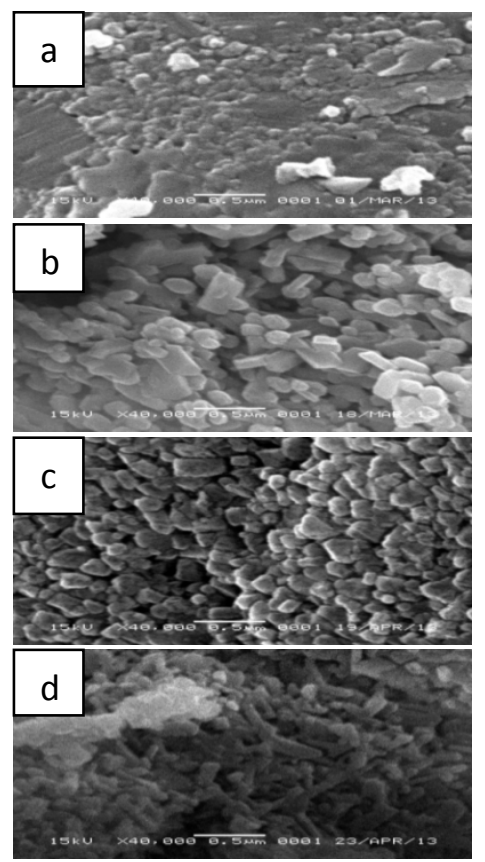

Gambar 1. Hasil SEM Mikrograf Contoh dengan Suhu Kalsinasi $750^{\circ} \mathrm{C}$ dan $0 \%$ Kitosan (a), 10\% Kitosan (b), $30 \%$ Kitosan (c), dan 60\% Kitosan (d)

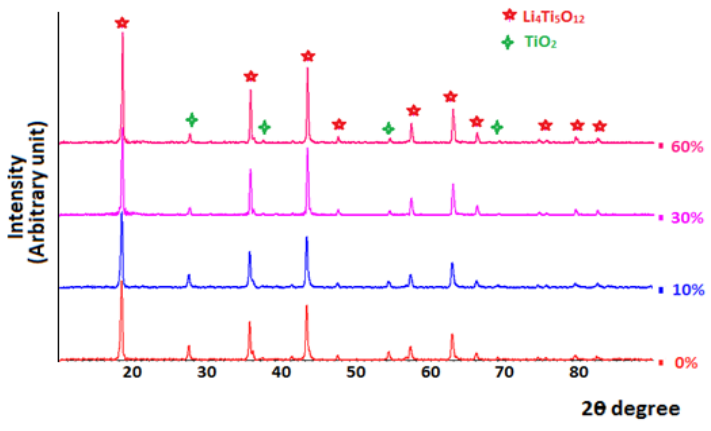

Gambar 2. Hasil XRD Berdasarkan Jumlah Kitosan dengan Suhu Kalsinasi $750^{\circ} \mathrm{C}$

Penelitian oleh Daniela Drago tentang pengaruh ukuran partikel terhadap kapasitas menjelaskan bahwa $\mathrm{Li}_{4} \mathrm{Ti}_{5} \mathrm{O}_{12}$ dengan ukuran partikel rata-rata antara 9-1000 nm dapat memberikan kapasitas yang mendekati kapasitas secara teori yaitu $175 \mathrm{mAh} /$ gram [5]. Dari seluruh contoh yang diuji, contoh dengan konsentrasi kitosan 30\% volume larutan menunjukkan partikel yang terdispersi paling merata dan berukuran paling kecil bila dibandingkan contoh lainnya yaitu antara 75$300 \mathrm{~nm}$ sehingga contoh ini paling berpotensi untuk digunakan sebagai metal anoda baterai lithium.

\section{KESIMPULAN}

1. Telah berhasil disintesis $\mathrm{Li}_{4} \mathrm{Ti}_{5} \mathrm{O}_{12}$ yang dapat berpotensi menjadi bahan anoda berbasis lithium dengan metode sol-gel dengan menggunakan kitosan sebagai dispersing agent.

2. Aglomerasi dari partikel paling banyak terjadi pada contoh tanpa kitosan sebagai dispersing agent. Konsentrasi kitosan 2\% $\mathrm{m} / \mathrm{v}$ sebesar $30 \%$ pelarut dan suhu kalsinasi $750^{\circ} \mathrm{C}$ menghasilkan morfologi partikel yang terdispersi merata dan berukuran 75-300 nm yang berpotensi untuk digunakan sebagai bahan anoda baterai lithium dengan kapasitas penyimpanan mendekati kapasitas teoritikal karena ukurannya yang lebih kecil dibandingkan contoh lainnya. 


\section{DAFTAR PUSTAKA}

[1] F. V. Conte, 2006, Battery and Battery Management for Hybrid Electric Vehicles, a review", E\&i Elektrotechnik und Informationstechnik, pp. 424-431.

[2] Isidor Buchmann, 2013, What's The Best Battery, Battery Univeristy.

[3] Ting-Feng Yi et al, 2013, "Structural and Thermodynamic Stability of $\mathrm{Li}_{4} \mathrm{Ti}_{5} \mathrm{O}_{12}$ Anode Metal for lithium-ion Battery", Journal of Power Sources, vol. 222, pp. 448454.
[4] M. Parans Paranthaman, 2011, High Performance Spherical Mesoporous Titanium Oxide Anode Based Lithium Ion Batteries, Oak Ridge National Laboratory, Oak Ridge.

[5] Daniela Drago. et al., Li-Insertion into $\mathrm{Li}_{4} \mathrm{Ti}_{5} \mathrm{O}_{12}$ (Spinel): Charge Capability vs. Particle Size and Electrolyte dependence in Thin-Film Electrodes, NTera, Ltd., Scientific Park, Switzerland. 